\title{
Structural differences arise between fruit cuticles of two apple cultivars during long term cold storage
}

\author{
Oszlányi, R. ${ }^{1}$, Tóth, M. ${ }^{2}$, Szabó, L. ${ }^{3}$ \& Papp, I. ${ }^{1}$ \\ ${ }^{1}$ Department of Plant Physiology and Plant Biochemistry, Faculty of Horticultural Science, Szent István University, \\ H -1118 Budapest, Hungary \\ ${ }^{2}$ Department of Pomology, Faculty of Horticultural Science, Szent István University, \\ H - 1118 Budapest, Hungary \\ ${ }^{3}$ Department of Functional and Structural Materials, Institute of Materials and Environmental Chemistry, \\ Research Centre for Natural Sciences, \\ Hungarian Academy of Sciences, $H$ - 1117 Budapest, Hungary \\ Author for correspondence: roszlanyi@gmail.com
}

\begin{abstract}
Summary: Apple fruits are covered by hydrophobic cuticle that provides protection against desiccation, pathogens, excessive water absorption and radiation. The features of cuticle affect the quality and storability of the fruits. It was aimed to evaluate the correlation between peel ultrastructure and weight loss in fruits covered by waxy bloom (cv. Florina) and without bloom (cv. Red Rome van Well) during 4-month cold storage. SEM (scanning electron microscopy) was used for visualization of the fruit surface and fruit weight was also measured. Several studies have revealed that there may be correlation between the ultrastructure of cuticle and its water permeability. Our results confirmed this phenomenon in case of two cultivars. The weight loss per fruit surface area unit of 'Florina' was found significantly higher than that of 'Red Rome van Well'. At the same time the cuticular surface of the fruits contained more micro-cracks in case of the former cultivar. These data confirmed the relationship between the density of cuticular micro-cracks and the water vapour permeability. We concluded that this feature is more significant than the amount of natural waxy bloom on fruit surface.
\end{abstract}

Oszlányi, R., Tóth, M., Szabó, L., Papp, I. (2018): Structural differences arise between fruit cuticles of two apple cultivars during long term cold storage. International Journal of Horticultural Science 24(3-4): 26-29. https://doi.org/10.31421/IJHS/24/3-4/1551

Key words: cuticle, fruit weight, long term storage, Malus domestica Borkh; micro-crack, SEM (scanning electron microscopy)

\section{Introduction}

The aerial surface of terrestrial plants is covered by hydrophobic cuticle layer (Curry, 2008; Albert et al., 2011) that plays an important protective role against environmental stresses (Tanaka et al., 2004). It also participates in cell-cell interactions, such as preventing organ fusion (Xia et al., 2009). This hydrophobic layer (Curry, 2008) which is produced by epidermal cells, acts as a barrier (Bringe, 2006) serving a primary line of defence against desiccation, harmful UV radiation, excessive water absorption, pathogen attack and herbivores (Tanaka et al., 2004; Albert et al., 2011; Konarska, 2013). It consists of two major constituents, cutin and cuticular waxes (Xia et al., 2009). The cutin matrix is integrated with the cell wall (Bringe, 2006). The cutin polymer is composed of covalently cross-linked epoxy- and hidroxy fatty acids (Curry, 2008; Xia et al., 2009). Intracuticular waxes are embedded in the cutin matrix while epicuticular waxes are the outermost layer of the cuticle. Both of them are composed of very long chain aliphatic aldehydes, primary, secondary and tertiary alcohols, alkanes, ketones and esters, all derived from very long-chain fatty acids (Curry, 2005; Konarska, 2012). Epicuticular waxes play important protective roles. Two types of epicuticular waxes can be distinguished: crystalline wax platelets of various dimensions/shapes and amorphous wax formations (Tessmer, et al., 2012; Konarska, 2013). Cuticular properties can affect ripening, growth and development of fruits, therefore information about its structure has important agronomical implications, influencing fruit quality (Albert et al., 2011). In apple increased wax biosynthesis in the epidermal cells occurs from the earliest stages of fruit development. Cuticle formation continues after harvesting and also during storage, with ultrastructure possibly changing during these stages. Micro-cracks can occur on the fruit surface because of growth of the fruit, or due to changes in amount and composition of cuticular components during storage. Microcracks may be repaired by newly formed wax, however they are more abundant, remaining wider and deeper at maturation and after storage (Tessmer et al., 2012; Konarska, 2013). The composition and thickness of apple fruit waxes are very diverse, they may be different among cultivars (Bringe et al., 2006; Tessmer et al., 2012). The storability of apple fruits depends on climatic and cultivation conditions during fruit development, proper timing of harvest and appropriate storage. It is also influenced by fruit characteristics, including cuticular traits. These influence water loss of fruits during storage through the entire storage period (Konarska, 2012). The amount of waxes increases during storage which in some cases is paralleled with the formation of microcracks on the surface. The deposition of wax platelets may cause repairing of these microcracks. Nonetheless the number of microcracks often increases and they become more extensive and deeper during 
storage. This process may result greater water loss (Tessmer et al., 2012), decreasing the weight and firmness of fruits. The amount of transpired water depends on some internal factors including the structure of the peel tissues, in particular that of the cuticle and properties of epicuticular wax (Konarska, 2012). Firmness, greasiness of surface and convenient storability are factors affected by the cuticle, influencing the marketable quality of apple fruits. Microcracks are thought to increase the permeability of cuticle for water thereby enhancing cuticular transpiration. Consequently the water loss of fruits may be correlated with number of microcracks on fruit surface. Regarding latter surface properties, differences in density of microcracks were observed among apples cultivars that were made visible on scanning electron micrographs of fruits peel (Konarska, 2013). Our research on two winter apple varieties aimed at establishing further correlation between microstructure of cuticle and storability of fruits.

\section{Materials and methods}

Two late ripening apple cultivars were chosen for our experiments: 'Florina' and 'Red Rome van Well' (Malus domestica Borkh). It is known that prominent natural waxy bloom is found on the fruit surface of 'Florina', while 'Red Rome van Well' develops shiny fruits with slight natural wax (Lespinnase et al.,1985; Soltész \& Szabó, 1998). Both cultivars were grown in the Experimental and Research Farm of Szent István University at Soroksár, Hungary. Fruits were harvested at full ripening in September 2014 and 2015. Their average size in 2014: 'Florina' height: $6.6 \pm 0.49$; width: $6.98 \pm 0.50$; 'Red Rome van Well' height: $7.2 \pm 0.63$; width: $7.34 \pm 0.55$. In 2015 'Florina' height: $6.08 \pm 0.77$; width: $6.5 \pm 0.66$; 'Red Rome van Well' height: $6.01 \pm 0.77$; width: $7.2 \pm 0.84$ [cm].

Fruits were chosen random from four sides of the trees in order to avoid micro climate effects. After harvest the weight of each fruits [g] was determined immediately, along with their measures in the three dimensions. The weight of fruits was also measured after two and four months in storage. Fruits were stored under controlled conditions $\left(3^{\circ} \mathrm{C}\right.$, Relative Humidity $90 \%$ ) for the four months period.

For SEM analysis fruit fragments $(1 \times 1 \mathrm{~cm}$ area were cut from the peels their thick were $0.5 \mathrm{~mm}$ ) (Curry et al., 2008) with peel were sampled at the beginning and in the end of storage. Collected tissues were stored at $-20{ }^{\circ} \mathrm{C}$ until lyophilisation. Samples were lyophilised (ScanVac CollSafe Basic 15 L Freeze Dryer, Denmark), then they were subjected to microscopic investigation. The lyophilized samples were observed by scanning electron microscope (ZEISS SmartSEM EVO 40-02-32, Germany) at 200x and 500x magnifications.

For surface area calculations the fruits were considered as spheres, thus the $\mathrm{A}=\pi \mathrm{r}^{2}$ formula was used ( $\mathrm{A}=$ surface area $\left[\mathrm{cm}^{2}\right], \mathrm{r}=$ average fruit diameter $\left.[\mathrm{cm}]\right)$. The weight loss of fruits [\%] was determined by calculating the difference between the starting and final weights of each fruits. Based on these data, weight loss per surface unit area of the fruits was calculated. We determine the weight loss [mg] according start weight was deducted from final weight and the weight loss per surface unit area $=$ weight loss $/$ surface area $\left[\mathrm{mg} / \mathrm{cm}^{2}\right]$ was calculated. The results were compared by Student t test (MS Excel 2013). Therefore, we could compare weight loss per unit surface area of the fruits in the two genotypes through the cold storage period. Moreover the relative weight loss per fruits in percent [\%] was also calculated (Table 1). 'Florina' $(\mathrm{n}=56)$ and 'Red
Rome van Well' ( $n=27$ ) fruits were harvested in the autumn of 2014. In 2015 a biological repetition of the experiments was made with 'Florina' $(n=35)$ and 'Red Rome van Well' $(n=42)$ pieces of fruits.

Table 1. Average relative weight loss (\%) of 'Florina' and 'Red Rome van Well' apples in 2014 and in 2015 ( \pm SD).

\begin{tabular}{|l|c|c|c|c|}
\hline \multirow{2}{*}{2014} & \multicolumn{2}{|c|}{ Florina } & \multicolumn{2}{c|}{ Red Rome van Well } \\
\cline { 2 - 5 } & Weight \% & $\begin{array}{c}\text { Weight } \\
\text { loss \% }\end{array}$ & Weight \% & $\begin{array}{c}\text { Weight } \\
\text { loss\% }\end{array}$ \\
\hline Start & 100 & 0 & 100 & 0 \\
\hline 2 months & $97.40 \pm 0.61$ & $2.60 \pm 0.61$ & $97.89 \pm 0.36$ & $2.10 \pm 0.36$ \\
\hline 4 months & $95.26 \pm 0.10$ & $4.74 \pm 0.10$ & $95.96 \pm 0.56$ & $4.04 \pm 0.56$ \\
\hline 2015 & \multicolumn{5}{|c}{} \\
\hline Start & 100 & 0 & 100 & 0 \\
\hline 2 months & $97.60 \pm 1.05$ & $2.40 \pm 1.05$ & $97.92 \pm 0.46$ & $2.10 \pm 0.46$ \\
\hline 4 months & $95.81 \pm 1.37$ & $4.18 \pm 1.37$ & $96.90 \pm 0.60$ & $3.10 \pm 0.60$ \\
\hline
\end{tabular}

\section{Results and discussion}

In 2014 the average weight loss per surface unit area of the fruits was significantly different between the cultivars. This was also observed in 2015 (Figure 1).

Fruit enlargement and maturation often result in microcracking of cuticle, that was proposed as a main contributor to water loss during storage (Curry et al., 2005). In apple cultivars the microcracks appear to varying degrees, thus the weight loss per surface unit area of fruits may be different. In our experiments, the weight loss per surface unit area of 'Florina' was significantly greater than that of 'Red Rome van Well'. Our results thus confirm major variations in the behaviour and structure of peel in the two cultivars. Several factors, as climatic conditions during growth together with genetic factors can profoundly affect the development of cuticle. The abundance, composition and structure of epicuticular wax are affected by the genetic background of the varieties. Apple cultivars with thicker cuticles may be prone to higher water loss rate due to more significant formation of microcracks that can be the basis of the higher water permeability. Composition of the epicuticular wax may also affect the intensity of cuticular transpiration. The texture of waxes (the proportion of crystalline and amorphous wax) may differ among cultivars. Amorphous wax may have a higher contribution to formation of microcracks. Varieties with rough peel are covered with wax enriched in the amorphous component, therefore more microcracks may develop on their surface (Konarska, 2012). In accordance with this expectation, according to our SEM micrographs 'Florina' fruits with rougher peel display more cuticular microcracks than 'Red Rome van Well' (Figures 2-5).

The difference observed in peel ultrastructure can possibly affect the storability of fruits of the two winter cultivars. Although storage atmosphere contains high humidity, the low water potential gradient can still drive noticeable water loss during the prolonged storage period (Table 1). The small amount of lost water may still result of shrivelling of fruits decreasing commercial value to various extent. Our results highlight the impact of structural and dynamic features of the surface wax layer in fruit storability. 

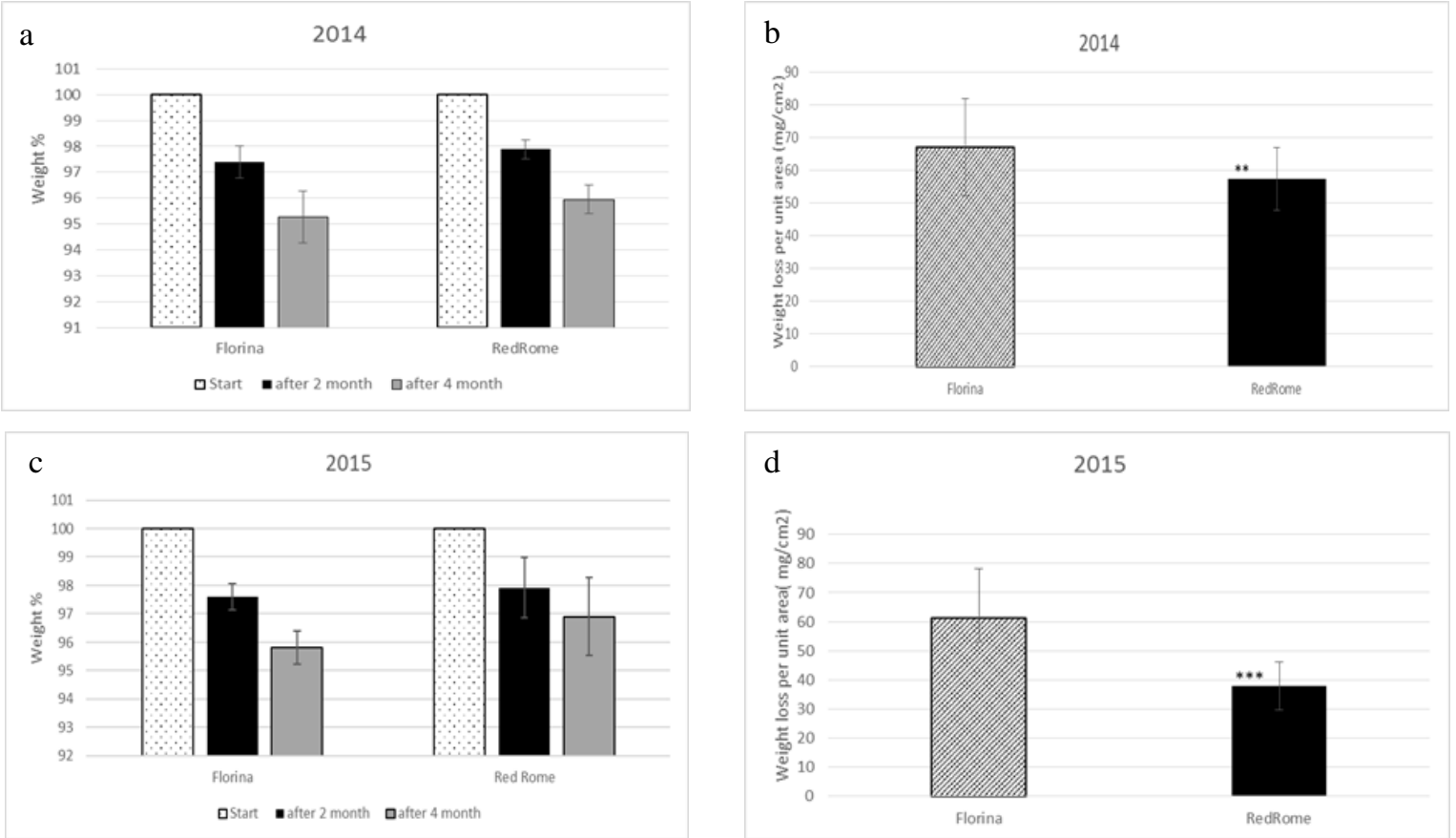

Figure 1. Comparison of relative weight loss (a, c) and weight loss per surface unit area (b, d) of 'Florina' and 'Red Rome van Well' fruits in 2014 and 2015. Vertical bars represent (SD). ** 0, 01<P; *** $\mathrm{P}<0,001$ according to Student two tails $t$ test.
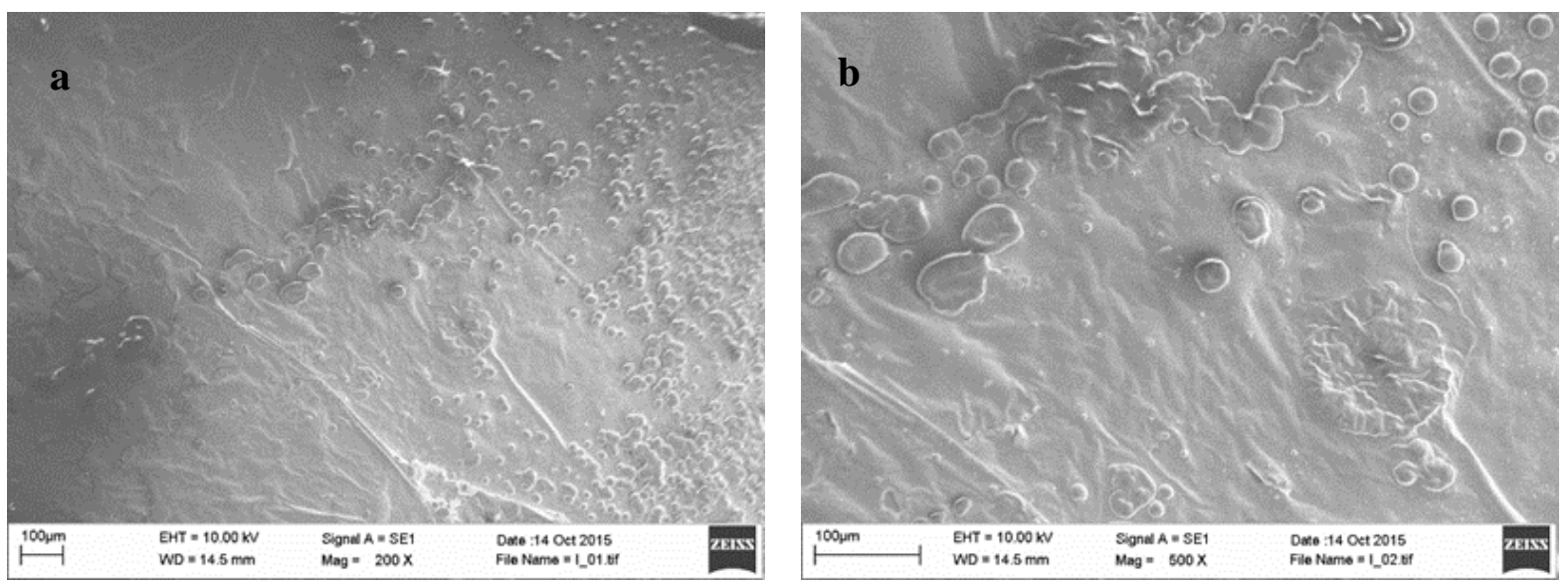

Figure 2. 'Florina' peel segment at 200x (a) and 500x (b) magnifications before storage.
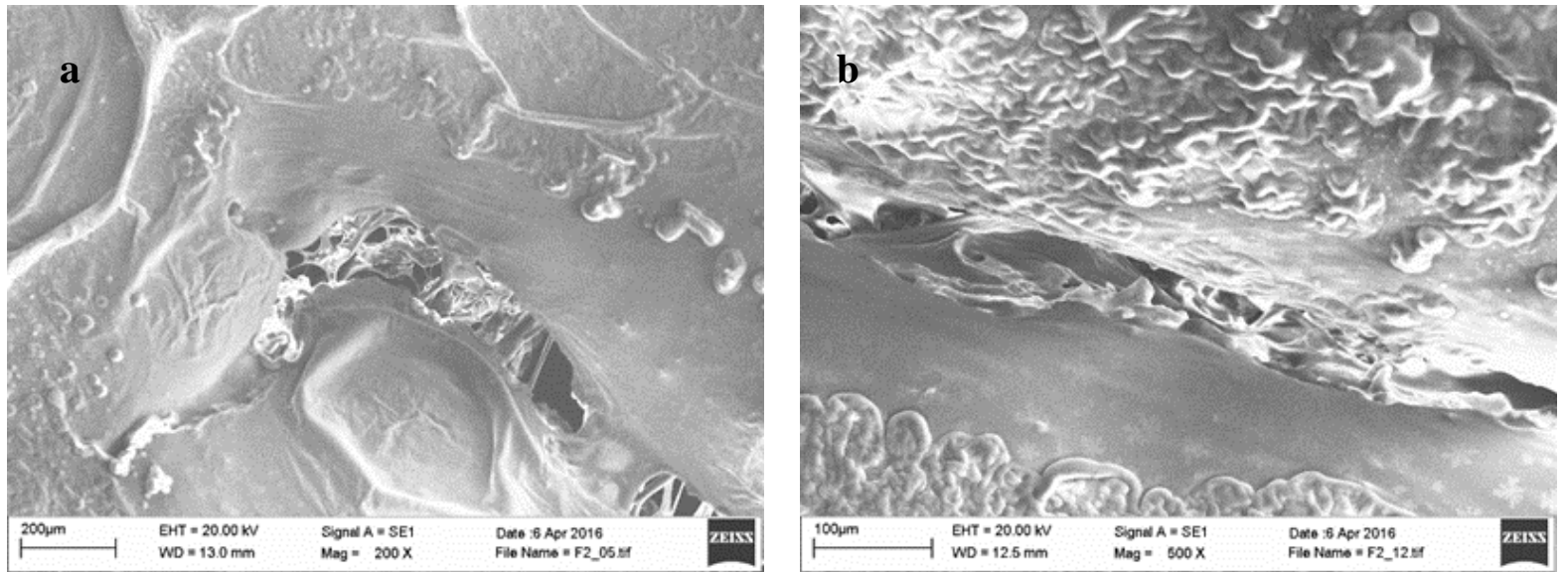

Figure 3. 'Florina' peel segments at 200x (a) and 500x (b) magnifications after storage. 

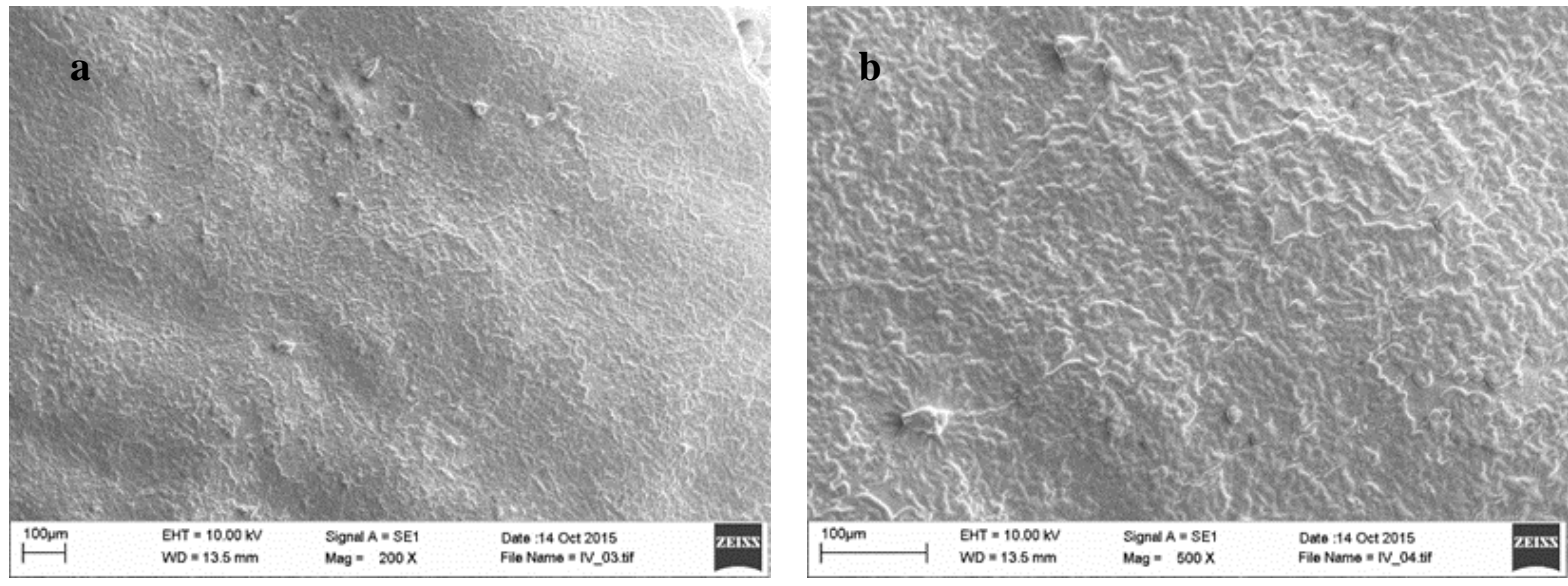

Figure 4. 'Red Rome van Well' peel segment at 200x (a) and 500x (b) magnifications before storage.
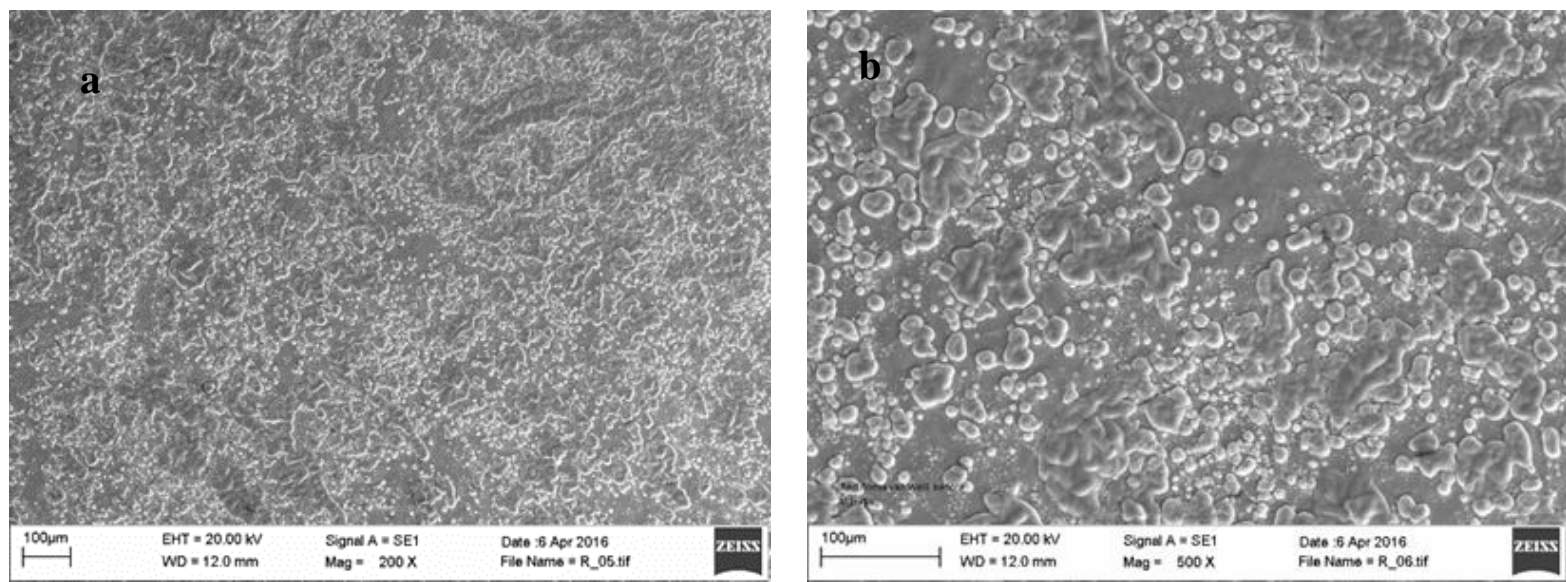

Figure 5. 'Red Rome van Well' peel segment at 200x (a) and 500x (b) magnifications after storage.

\section{Acknowledgements}

This research was supported by the Higher Education Institutional Excellence Program (1783-3/2018/ FEKUTSTRAT) awarded by the Ministry of Human Capacities within the framework of water related researches of Szent István University.

\section{References}

Albert, Zs., Ivanics, B., Molnár, A., Deák, Cs., Miskó, A., Tóth, M., Papp, I. (2011): Characterization of gene expression in apple, connected potentially to cuticular wax production. Acta Biologica Szegediensis, 55 (1): 59-61.

Bringe, K., (2006): Surface characteristic of Malus domestica Borkh. leaves and fruits as influenced by ontogenesis and environmental factors. Cuvilier Verlag Göttingen, Berlin.

Curry, E., A. (2005): Ultrastructure of epicuticular wax aggregates during fruit development in apple (Malus domestica Borkh.). Journal of Horticultural Science \& Biotechnology $\quad 80 \quad(6): \quad 668-676 . \quad$ DOI: 10.1080/14620316.2005.11511996

Curry, E., A. (2008): Effects of 1-MCP applied porstharvest on epicuticular wax of apples (Malus domestica Borkh.) during storage. Journal of Science of Food and Agriculture, 88: 996-1006. https://doi.org/10.1002/jsfa.3180

Konarska, A. (2012): The structure of the fruit peel in two varieties of Malus domestica Borkh. (Rosaceae) before and after storage. Protoplasma, 250 (3):701-14. DOI 10.1007/s00709-012-0454-y
Konarska, A. (2013): Morphological, histological and ultrastructural changes in fruit epidermis of apple Malus domestica cv. Ligol (Rosaceae) at fruit set, maturity and storage. Acta Biologica Cracoviensia Series Botanica 56 (2): 1-14. 2014 DOI: 10.2478/abcsb-2014-0019

Lespinasse, Y., Olivier, J. M., Lespinasse, J., M., Lezec, L. M. (1985): Florina Quérina la résistance du pommier á la tavelure. L' arboriculture fruitiere. 378: 43-47.

Soltész, M., Szabó, T. (1998): Alma. (Apple.), 119-155. In: Soltész M. (ed.): Gyümölcsfajta-ismeret és használat. (Knowledge and uses of fruit cultivars.) Mezőgazda Kiadó, Budapest.

Tanaka, T., Tanaka, H., Machida, C., Watanabe, M., Machida, Y. (2004): A new method for rapid visualization of defects in leaf cuticle reveals five intrinsic patterns of surface defects in Arabidposis. The Plant Journal. 37(1): 139-146. doi: 10.1046/j.1365-313X.2003.01946.x

Tessmer, M., A., Antoniolli, L., R., Apezzato-Da-Glória B. (2012): Cuticle of 'Gala' and 'Galaxy' apples cultivars under different environmental conditions. Brazilian Archives of Biology and Technology. 55:709-714. http://dx.doi.org/10.1590/S1516-89132012000500010

Xia Y. M., Gao Q., Yu K., Lapchyk L., Navarre D., Hildebrand D., Kachroo A., Kachroo P. (2009): An act cuticle in distal tissues is essential for the induction on systemic acquired resistance in plants. Cell Host \& Microbe 5:151-165. Doi: 10.1016/j.chom.2009.01.001 